 \\ International Journal of Social Sciences and Management
}

\section{A Rapid Publishing Journal}

ISSN 2091-2986

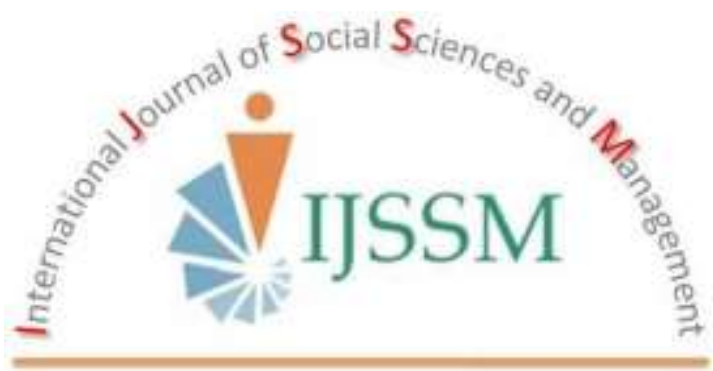

\section{Indexing and Abstracting}

CrossRef, Google Scholar, International Society of Universal Research in Sciences (EyeSource), Journal TOCs, New Jour, Scientific Indexing Services, InfoBase Index, Open Academic Journals Index (OAJI), Scholarsteer, Jour Informatics, Directory of Research Journals Indexing (DRJI), International Society for Research Activity (ISRA): Journal Impact Factor (JIF), Simon Fraser University Library, etc.

Vol-2(1) July, 2015

SEM-Biotech

Publishing

Impact factor ${ }^{*}: \mathbf{3 . 3 8 9}$ 


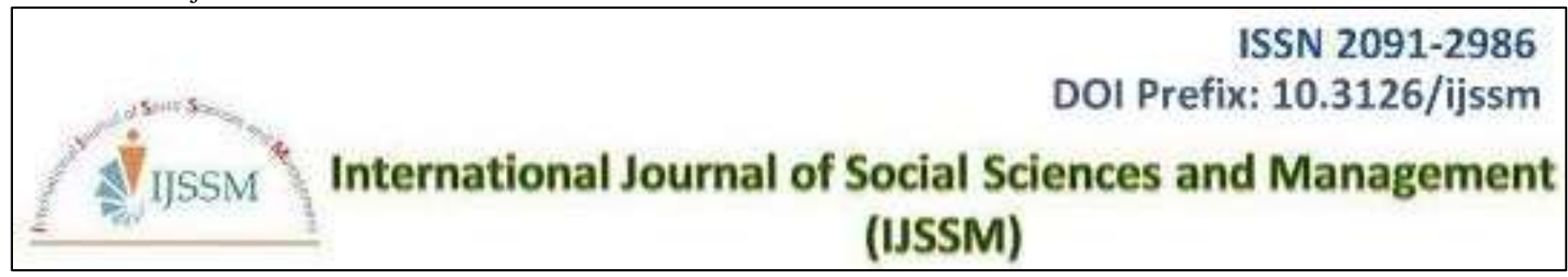

Research Article

\title{
FINANCIAL ASSESSMENT OF PUBLIC AND PRIVATE BANKS IN INDIA
}

\author{
Swaricha Johri ${ }^{1 *}$ and Manjeet Singh ${ }^{2}$ \\ ${ }^{1}$ Department of Commerce Aligarh Muslim University, Aligarh, India \\ ${ }^{2}$ ClearTrail Technologies Pvt. Ltd. (Company), Greater Noida, India \\ *Corresponding author's email: swaricha.amu@gmail.com
}

\begin{abstract}
The banking sector is the backbone of the economy and plays an important financial intermediary role, their health is very critical to the health of the general economy at large. In order to ensure a healthy, solid and stable banking sector, the banks must be analyzed and evaluated in a way that will allow the smooth correction and removal of the potential vulnerabilities. The present study is done with the objective to analyze the financial performance of the commercial banks in India. CAMEL Approach is applied to evaluate the financial performance of SBI and ICICI bank. Based on the set of indicators as defined by CAMEL framework the financial performance is being evaluated with the help of various ratios. Comparison of financial performance was done by applying Independent sample t- test. The study concluded that ICICI bank is more efficient in terms of capital adequacy and can resists risk more effectively that SBI. The financial statements of SBI \& ICICI bank from the period of 2009-10 to 2013-14 have been analyzed for the purpose of the study. Whereas SBI's earning capabilities are far better than ICICI. More or less both banks are carrying on their operations effectively.
\end{abstract}

Keywords: Financial Performance, CAMEL, Commercial Banks and Efficiency.

\section{Introduction}

The Economic development of any country largely depends upon its manufacturing and banking sector. Banks plays a very significant role in the development of the country. Over the last few years, major structural changes have occurred in the Indian banking system. The sharp decline in the domestic currency has resulted in damaging effects on the leading banks' balance sheets and their capital adequacy. In response to the depreciating exchange rate, the central bank of India lifted interest rates on deposits. This has resulted in bank revenues to decline, as banks could not pass on higher interest rates to distressed corporate borrowers, sub sequent resulting in negative interest rate spreads and reducing banks' net income. It is reasonable to assume that these changes posed great challenges to financial institutions in India as the environment in which they operated changed rapidly, a fact that consequently had an impact on the determinants of the profitability of Indian banks. In this way, one of the most popular methods for the analysis and evaluation of the banks soundness is represented by the CAMELS framework (Fs Mishkin, 1999; Chandra Shekhar, 2011). The aim of our research is to analyze the financial soundness of the commercial banks that operate in public and private sector of India. In order to achieve this aim our methodology is based on the CAMELS framework which has been created in 1979 in USA by the bank regulatory agencies. The acronym CAMEL derives from the five main segments of a bank operations: Capital adequacy, Asset quality, Management quality, Earnings ability and Liquidity.

\section{Indian banking industry}

Indian banking industry consists mainly of nationalized banks on the one hand, and private, foreign, sect oral and cooperative banks on the other (Kumar and Singh, 2006). This industry has been undergoing unprecedented transformation since the Government of India adopted economic liberalization, privatization, and globalization policies in early 1990s. However, in the changed business environment, domestic as well as global, the Indian banking sector cannot remain unaffected. These unprecedented changes have created a completely new competitive landscape. Deregulation has opened up new opportunities for the banks to increase their revenues by diversifying into investment banking, insurance, credit cards, depository services, mortgage financing, securitization, etc. But, at the same time, the economic reforms and privatization reforms have brought greater competition among banks, both domestic and foreign, as well as competition from mutual funds, NBFCs, post office, etc. Increasing competition is squeezing profitability and forcing banks to work efficiently.

Since the early 1990s, the structure of the banking sector has significantly changed due to deregulation and liberalization, accompanied by divestment of public banks 
and entry. These developments are expected to have important implications for operating performance and profitability in the banking system.

The origin of modern commercial banking in India can be associated with the setting up of the first Presidency bank, the Bank of Bengal, in Calcutta in 1806. Two other Presidency banks were set up in Bombay and Madras in 1840 and 1843 respectively. The present study is focused on the most important public sector bank SBI and private sector bank ICICI. These two banks have covered the huge share of customers who are seeking multi-dimensional banking services. Table 1 shows a brief profile of both the banks.

\section{Literature Reviews}

Many studies have been conducted on the banking sector of India and various authors have done the study focused on the comparative study of financial performance of the Indian banks some of these are:

Kumar and Singh (2006) empirically found that all four components of competitiveness under study: Quality efficiency and governance, economic efficiency, social responsibility, and performance stability and overall competitiveness were influenced by different sets of strategies. They carried their study through ordinary least square technique on Indian Nationalized Banks. The study suggested that the introduction of innovative products and services was perceived to contribute significantly both towards quality efficiency and economic efficiency. Expansion policies significantly influenced the social responsibility and performance stability components of bank's competitiveness.

Sensarma, (2005) by using Stochastic Frontier Analysis have done the study on Scheduled Commercial Banks.

Table 1: Brief Profile of SBI \& ICICI Bank:
Their study found that the cost efficiency of the banking industry increased during 1983-2003 period, profit efficiency underwent a decline. This result is expected in an emerging economy undergoing a process of deregulation. In terms of bank groups, domestic banks appear to be more efficient than foreign banks.

Mohan, (2002) in their paper, study about the deregulation and performance of Public Sector Banks. The study is done with the help of financial ratios of India's public sector banks. They found that the only parameter on which the public sector does better is the net interest income/total assets or what is called the 'spread'. The public sector's performance is also inferior to that of foreign banks on three out of four parameters. In this comparison, the public sector does better on the ratio of intermediation costs to total assets.

Mohan and Ray (2004) in their study compared the performance of public and private sector banks by using data envelopment analysis Public. The study founded that public sector banks performed significantly better than private sector banks but no differently from foreign banks. The superior performance of public sector banks was to be ascribed to higher technical efficiency rather than higher allocative efficiency

Roman and Şargu (2013) analyzed the Financial Soundness of the Commercial Banks in Romania by using the CAMELS framework. The obtained results highlighted the strengths and the vulnerabilities of the analyzed banks, underlining the need to strengthen the concerns of the decision makers from banks to improve and increase their soundness.

\begin{tabular}{|c|c|c|}
\hline Differences & SBI & ICICI \\
\hline Nature & SBI is a government owned bank (public sector & $\begin{array}{l}\text { An Indian Multinational Bank ICICI is a } \\
\text { privately owned bank (private sector) }\end{array}$ \\
\hline Headquarter & Mumbai & Vadodara \\
\hline Branches & 17,000 & 3,800 \\
\hline ATMs & 56,000 & 11,162 \\
\hline Existence & SBI is much older (more than 200 years old) & less than 25 years old \\
\hline $\begin{array}{l}\text { International } \\
\text { Transfer } \\
\text { Amount }\end{array}$ & $\begin{array}{l}\text { The SBI does not limit daily international transfer } \\
\text { amounts, }\end{array}$ & $\begin{array}{l}\text { While the ICICI Limits daily transfers to } \\
\$ 5000 \text { a day. }\end{array}$ \\
\hline $\begin{array}{l}\text { Interest on } \\
\text { Deposits }\end{array}$ & Higher. & Lower \\
\hline $\begin{array}{l}\text { Services } \\
\text { Provided }\end{array}$ & $\begin{array}{l}\text { Demand Drafts, Operations Manager (Queries), } \\
\text { Deposits / Withdrawals, Pass Book Entries, Queries, } \\
\text { Clearing } \\
\text { May I Help You }\end{array}$ & $\begin{array}{l}\text { Operations Manager (Complaints),New } \\
\text { Accounts, NRI / Forex, Deposits, May I Help } \\
\text { You ,Fixed Deposits and Others, Loans, } \\
\text { DEMAT, Mutual Funds }\end{array}$ \\
\hline $\begin{array}{l}\text { Services } \\
\text { provided by the } \\
\text { ATMs }\end{array}$ & $\begin{array}{l}\text { Cash Withdrawal ,Mobile Recharge ,Fund Transfers } \\
\text {,Bills (All),Mini Statement Balance Enquiry, Donate to } \\
\text { temple trusts ,Donate to relief funds ,(MTNL and } \\
\text { Bescom only) ,Pay SBI Credit Card Bills ,Balance } \\
\text { Enquiry ,Pay SBI Life Insurance premium, Pay fees of } \\
\text { certain colleges }\end{array}$ & $\begin{array}{l}\text { Cash Withdrawal ,Mobile Recharge, Pay } \\
\text { Utility ,Pay ICICI credit card bills ,Pay ICICI } \\
\text { Prudential Insurance premium, Request } \\
\text { cheque book ,Fund Transfers, pay Utility } \\
\text { Bills, Mini Statement }\end{array}$ \\
\hline
\end{tabular}


Habibullah (2010)Assessed the Impact of Financial Crisis on Bank Performance of Indonesian banks the empirical findings indicate that income diversification and capitalization are positively related to bank profitability, while size and overhead costs exert negative impacts. The Asian financial crisis exerts negative and significant impact on the profitability of Indonesian banks, while Indonesian banks have been relatively more profitable during the precrisis compared to the post-crisis and crisis periods.

Mohan (2002) In their study used Stochastic Frontier Analysis (SFA) to evaluate the Long-Run Performance of Public and Private Sector Bank Stocks. The study found that PSB stocks' performance on the average was not significantly different from that of the Sensex or from that of private sector bank stocks. Since the particular research stream has now includes hundreds of studies, only most relevant and important are reviewed. On the basis of the above literature review it was found that no such study has been done using CAMEL framework taking SBI and ICICI bank as sample for study. Present study is focused to compare the financial performance of SBI and ICICI bank using CAMEL framework

\section{Objectives of Study}

1. To analyze the financial Soundness of SBI \& ICICI Bank by using CAMELS Approach

2. To compare the financial performance of SBI \& ICICI Bank

\section{Methodology}

In the present study, an attempt has been made to measure, evaluate and compare the financial performance of a public sector bank SBI and a private sector Bank ICICI. The study is based on secondary data that has been collected from annual reports of the respective banks, magazines, journals, documents and other published information. The study covers the period of 5 years i.e. from year 2009-10 to year 2013-14. CAMELS Approach was being applied to evaluate the financial performance of both the banks.
Comparison of financial performance was being done by applying Student T Test through SPSS.

\section{Hypotheses}

1. There is no significant difference between Capital Adequacy of SBI and ICICI Bank.

2. There is no significant difference between Asset Quality of SBI and ICICI Bank in terms of:

- Total Asset turnover ratio

- Asset turnover ratio

- Loan Turnover Ratio

3. There is no significant difference between Management Efficiency of SBI and ICICI Bank in terms of:

- Credit Deposit Ratio

4. There is no significant difference between Earning Ability of SBI and ICICI Bank in terms of:

- Net Profit Ratios

- Return on Net Worth

- Dividend per Share

- Earnings per Share

- Return on Assets

5. There is no significant difference between Liquidity of SBI and ICICI Bank in terms of:

- Current Ratio

- Quick Ratio

\section{Comparative Financial Performance of SBI \& ICICI Bank}

In the present study the financial performance of SBI and ICICI bank has been analyzed through Camels Approach which is as under:

In the Table 2 and Table 3 researcher has analyzed the financial performance of the two banks on the basis of CAMEL approach. For this the financial and accounting ratios have been calculated. The ratios that satisfy all the aspects of CAMEL are taken into consideration. A comparison of financial performance of SBI and ICICI bank has been done on the basis of these ratios;

Table 2: Financial Performance of SBI: CAMEL Approach

\begin{tabular}{|c|c|c|c|c|c|c|c|c|c|c|c|c|}
\hline & C & \multicolumn{3}{|c|}{$\overline{\mathbf{A}}$} & M & \multicolumn{5}{|c|}{$\mathbf{E}$} & \multicolumn{2}{|c|}{$\mathbf{L}$} \\
\hline Year & CAR & TATR & ATR & LTR & CDR & NPR & RONW & DPS & EPS & ROA & CR & QR \\
\hline $2009-10$ & 13.39 & .09 & .09 & .15 & 75.96 & 10.54 & 13.89 & 30 & 144.37 & 1038.76 & .04 & 9.07 \\
\hline $2010-11$ & 11.98 & .07 & .08 & .26 & 36.36 & 7.58 & 12.71 & 30 & 116.07 & 1023.40 & .04 & 8.50 \\
\hline 2011-12 & 13.86 & .08 & .09 & .28 & 55.67 & 9.68 & 13.94 & 35 & 174.46 & 1251.05 & .05 & 12.05 \\
\hline 2012-13 & 12.92 & .08 & .09 & .13 & 85.17 & 10.39 & 14.26 & 41.50 & 206.20 & 1445.60 & .04 & 12.15 \\
\hline 2013-14 & 12.96 & .08 & .09 & .12 & 86.84 & 7.03 & 9.2 & 30 & 145.88 & 1584.34 & .03 & 13.88 \\
\hline
\end{tabular}

Source: Compiled By Authors from the Data collected through CMIE Prowess, RBI website, and Money Control.com 
Table 3: Financial Performance of ICICI: CAMEL Approach

\begin{tabular}{|c|c|c|c|c|c|c|c|c|c|c|c|c|}
\hline & $\mathrm{C}$ & \multicolumn{3}{|c|}{$\overline{\mathbf{A}}$} & $\mathbf{M}$ & \multicolumn{5}{|c|}{$\mathbf{E}$} & \multicolumn{2}{|c|}{$\mathbf{L}$} \\
\hline Year & CAR & TATR & ATR & LTR & CDR & NPR & RONW & DPS & EPS & ROA & CR & QR \\
\hline 2009-10 & 19.41 & .09 & .10 & .17 & 90.04 & 12.17 & 7.79 & 12 & 36.10 & 463.01 & .14 & 14.70 \\
\hline $2010-11$ & 19.54 & .07 & .07 & .13 & 90.45 & 15.79 & 9.35 & 14 & 44.73 & 478.31 & .07 & 15.86 \\
\hline 2011-12 & 18.52 & .07 & .08 & .14 & 97.71 & 15.75 & 10.70 & 16.50 & 56.09 & 524.01 & .12 & 9.37 \\
\hline 2012-13 & 18.74 & .08 & .08 & .34 & 65.57 & 17.19 & 12.48 & 20 & 72.22 & 578.21 & .98 & 10.53 \\
\hline 2013-14 & 17.70 & .08 & .08 & .26 & 54.23 & 17.96 & 13.40 & 23 & 84.95 & 633.92 & .09 & 11.31 \\
\hline
\end{tabular}

Source: Compiled By Authors from the Data collected through CMIE Prowess, RBI website, and Money Control.com

\section{Limitations of the study}

1. The study has focused only on Public Sector Bank SBI \& Private Sector Bank ICICI and did not consider other sector of the economy due to inadequacy of time and resources.

2. The study has ignored the impact of possible differences in the accounting method adopted.

3. The Present study is based on the secondary data of both the banks that has some limitations in itself.

\section{Analysis and Interpretation}

In Table 4 the researchers have selected some ratios on the basis of the CAMEL approach to compare the financial performance of SBI and ICICI bank. The Levene's t test for equality of variances has been taken into consideration as the purpose of this test is to determine whether the variances between the two groups are significantly different from each other. This is important because one of the assumptions of the independent $t$ test is that the two groups have equal variances. The $\mathrm{p}$ value in the above table is greater than 0.05 , than we can assume that variances are equal and the values with equal variances are taken into consideration in the present study.

A t test for independent samples associated with H1: "There is no significant difference between Capital Adequacy of SBI and ICICI Bank", revealed that there exist a significant difference in the capital adequacy of both the banks SBI and ICICI bank as the values of $\mathrm{t}=-12.648, \mathrm{p}=.000, \mathrm{p}<.05$. So the null hypothesis is not supported. ICICI bank has reported significantly greater positive values $(M=18.7820$, $\mathrm{SD}=.31126)$ than SBI $(\mathrm{M}=13.0220, \mathrm{SD}=.696000)$ that shows ICICI bank is more efficient to counter the risk exposures or unexpected loss against its capital than SBI.

The asset quality of both SBI and ICICI bank are same on the basis of total asset turnover ratio. The mean value of both the banks is very less differing (SBI, M=.0800, $\mathrm{SD}=.00707$; ICICI, $\mathrm{M}=.0780, \mathrm{SD}=.00837$ ) but the result of $\mathrm{t}$ test for H2: "There is no significant difference between Asset Quality of SBI and ICICI Bank in terms of "Total
Asset turnover ratio" "Asset turnover ratio" \& "Loan Turnover Ratio"

Revealed that there is no significant difference between the two banks on the basis of total asset turnover ratio as $\mathrm{t}=.408$, $\mathrm{p}=.694, \mathrm{p}>.05$.

If we see the asset turnover ratio than SBI has greater positive values than ICICI bank (SBI, M=.0880, $\mathrm{SD}=.00447$; ICICI, $\mathrm{M}=.0820, \mathrm{SD}=.01095)$ and statistically the result of $\mathrm{T}$ test revealed that there is no significant difference between SBI and ICICI bank in Asset turnover ratio as $\mathrm{t}=1.134, \mathrm{p}=.290, \mathrm{p}>.05$.

SBI is showing greater positive value in terms of loan turnover ratio than ICICI bank. (SBI, M=.1880, $\mathrm{SD}=.07596$; ICICI, $\mathrm{M}=.2080, \mathrm{SD}=.08983$ ). Independent $\mathrm{t}$ statistics revealed that there is no significant difference among both the banks for loan turnover ratio as $\mathrm{t}$ value is .380 and $p=.714, p>.05$. so from the above table 3 we can say that the $\mathrm{H} 2$ is supported statistically as per the result show by the t test.

Management efficiency of ICICI is better than SBI as the value of ICICI is showing greater values in terms credit deposit ratio (SBI, $\mathrm{M}=68.000, \mathrm{SD}=.21 .5997$; ICICI, $\mathrm{M}=79.6000, \mathrm{SD}=18.67596)$. $\mathrm{T}$ test for $\mathrm{H} 3$ : There is no significant difference between Management Efficiency of SBI and ICICI Bank in terms of "Credit Deposit Ratio"

Revealed that there is no significant difference between SBI $\&$ ICICI in terms of Credit deposit ratio as $\mathrm{t}=-.908, \mathrm{p}=.390$, p>.05. The null hypothesis is supported statistically.

Earning ability of the two banks SBI and ICICI is being compared on the basis of five parameters.Net profit of ICICI bank is more as compared to SBI as ICICI bank is showing greater values (SBI, $\mathrm{M}=9.0440, \mathrm{SD}=1.63200$; ICICI, $\mathrm{M}=$ 15.7720, $\mathrm{SD}=2.22336$ ).

$\mathrm{T}$ test for the H4: There is no significant difference between Earning Ability of SBI and ICICI Bank in terms of: "Net Profit Ratios" "Return on Net Worth" "Dividend per Share" "Earnings per Share"\& "Return on Assets"

Revealed that there is a significant difference between SBI $\&$ ICICI in terms of net profit, $\mathrm{t}=-5.455, \mathrm{p}=.001, \mathrm{p}<.05$ so the null hypothesis is not supported statistically. 
Table showing Comparison of SBI with ICICI

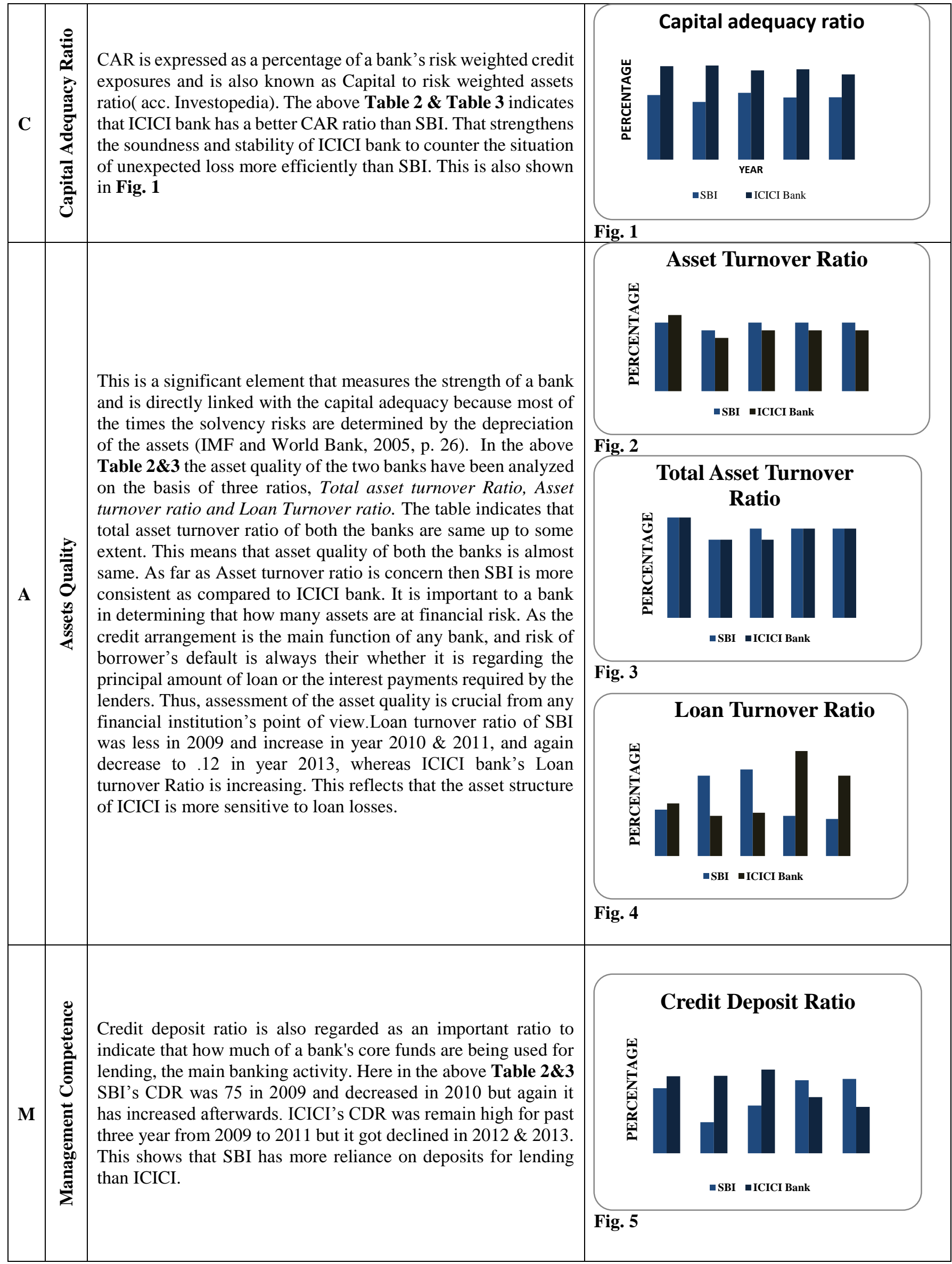




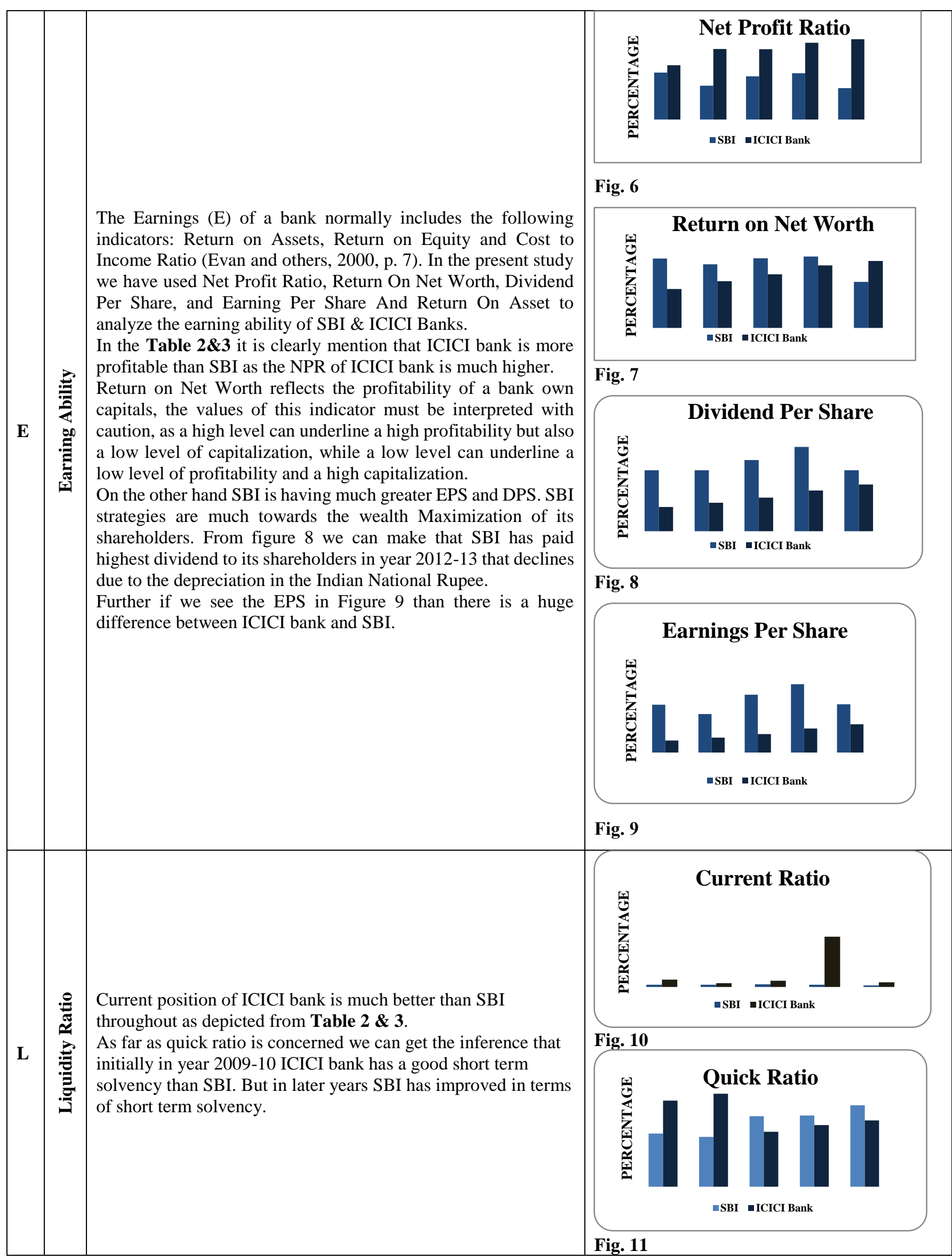


Table 4: T test for Equality of Mean: Financial Performance of SBI and ICICI Bank.

\begin{tabular}{|c|c|c|c|c|c|c|c|}
\hline \multirow{2}{*}{ Variable } & \multicolumn{2}{|c|}{ SBI } & \multicolumn{2}{|c|}{ ICICI } & \multirow{2}{*}{$\begin{array}{c}\mathbf{T} \\
\text { value }\end{array}$} & \multirow{2}{*}{$\begin{array}{c}\text { Sig } \\
\text { Value }\end{array}$} & \multirow{2}{*}{$\begin{array}{c}\text { HO } \\
\text { Accepted/Rejected }\end{array}$} \\
\hline & $\mathbf{M}_{1}$ & $\mathbf{S}_{1}$ & $\mathbf{M}_{2}$ & $\mathbf{S}_{2}$ & & & \\
\hline Capital Adequacy & 13.0220 & .69600 & 18.7820 & .31126 & -12.648 & .000 & Reject \\
\hline \multicolumn{8}{|l|}{ Asset Quality } \\
\hline $\begin{array}{l}\text { Total Asset } \\
\text { ratio }\end{array}$ & .0800 & .00707 & .0780 & .00837 & .408 & .694 & Accept \\
\hline Asset turnover ratio & .0880 & .00447 & .0820 & .01095 & 1.134 & .290 & Accept \\
\hline Loan Turnover Ratio & .1880 & .07596 & .2080 & .08983 & -.380 & .714 & Accept \\
\hline \multicolumn{8}{|l|}{ Management Efficiency } \\
\hline Credit Deposit Ratio & 68.000 & 21.5997 & 79.6000 & 18.67596 & -.908 & .390 & Accept \\
\hline \multicolumn{8}{|l|}{ Earning Ability } \\
\hline Net Profit Ratios & 9.0440 & 1.63200 & 15.7720 & 2.22336 & -5.455 & .001 & Reject \\
\hline Return on Net Worth & 12.8000 & 2.09687 & 10.7440 & 2.27702 & 1.485 & .176 & Accept \\
\hline Dividend per Share & 33.3000 & 5.06952 & 17.1000 & 4.44972 & 5.370 & .001 & Reject \\
\hline Earnings per Share & 157.3960 & 34.21675 & 58.8180 & 19.90299 & 5.569 & .001 & Reject \\
\hline Return on Assets & 1268.6300 & 247.12255 & 535.4920 & 71.00732 & 6.376 & .000 & Reject \\
\hline \multicolumn{8}{|l|}{ Liquidity } \\
\hline Current Ratio & .0400 & .00707 & .2800 & .39224 & -1.368 & .209 & Accept \\
\hline Quick Ratio & 11.1300 & 2.26990 & 12.3540 & 2.78913 & -.761 & .468 & Accept \\
\hline
\end{tabular}

Source: Prepared by Authors From SPSS analysis table.

The mean value of SBI is more than ICICI Bank in terms of Return on Net Worth (SBI, M = 12.8000, SD =2.09687; ICICI, $\mathrm{M}=10.7440, \mathrm{SD}=2.27702$ ). And $\mathrm{t}$ statistics supports that there is no difference among both the banks, $\mathrm{t}$ $=1.485, \mathrm{p}=.176, \mathrm{p}>.05$.

The mean value for Dividend per Share of SBI is greater than ICICI bank (SBI, M = 33.3000, SD =5.06952; ICICI, $\mathrm{M}=17.1000, \mathrm{SD}=4.44972$ ). $\mathrm{T}$ statistics indicates that there is a difference among both the banks, $\mathrm{t}=5.370, \mathrm{p}=.001$, $\mathrm{p}<.05$

Similarly, SBI has greater mean values in terms of Earnings per Share (SBI, $\mathrm{M}=157.3960, \mathrm{SD}=34.21675$; ICICI, $\mathrm{M}=$ $58.8180, \mathrm{SD}=19.90299)$; as well as Return on assets(SBI, $\mathrm{M}=1268.6300, \mathrm{SD}=247.12255$; ICICI, $\mathrm{M}=535.4920, \mathrm{SD}$ $=71.00732$ ).t values indicates that there is a significant difference among both the banks statistically (EPS, $\mathrm{t}=$ 5.569, $\mathrm{p}=.001, \mathrm{p}<.05)(\mathrm{ROA}, \mathrm{t}=6.376, \mathrm{p}=.000, \mathrm{p}<.05)$. This shows that SBI is more profitable as compared to ICICI bank.

ICICI bank has more sound liquidity position than SBI. ICICI bank has shown greater positive values than SBI in terms of current ratio (SBI, M=.0400, SD=.00707; ICICI, $\mathrm{M}=.2800, \mathrm{SD}=.39224)$. Statistically there is no significant difference between the current position of both the banks as revealed by independent $\mathrm{t}$ test $(\mathrm{t}=-1.368, \mathrm{p}=.209, \mathrm{p}>.05$. $)$ for the H5: There is no significant difference between Liquidity of SBI and ICICI Bank in terms of: "Current Ratio"\& "Quick Ratio". In terms of quick ratio also ICICI has greater values (SBI, M=11.1300, SD=2.26990; ICICI, $\mathrm{M}=12.3540, \mathrm{SD}=2.78913$ ) and there is again no significant difference between the liquid position of both the banks that has been revealed by $\mathrm{t}$ statistics, $\mathrm{t}=-.761, \mathrm{p}=.468, \mathrm{p}>.05$. So the null hypotheses for the liquidity position of banks are significant hence supported statistically.

\section{Conclusion}

In the present study we aimed to highlight the soundness of two banking institutions, one operates in public sector "SBI" and another operates in the private sector bank "ICICI". This has been done through certain indicators that express the main content of the CAMEL framework. Based on the set of indicators that reflects the financial soundness 
of the two banks our study concludes that ICICI bank is more efficient to counter the risk exposures or unexpected loss against its capital than SBI. Asset quality of both the banks was very much similar. ICICI bank is more efficient in terms of managerial efficiency as ICICI bank has more credit deposit ratio. SBI is far better in terms of return on asset, return on net worth, dividend per share and earning per share whereas, ICICI has better profitability position. The short term liquidity position of ICICI is much better than SBI. As these two banks are covering the major market share with huge customer base so this study is useful in acknowledging the strengths and weaknesses of these two banks.

As future research directions, we intend to empirically assess the impact of major factor on financial soundness of banks operating in India.

\section{References}

Habibullah FS (2010) Assessing the Impact of Financial Crisis on Bank Performance: Empirical Evidence from Indonesia. 27(3): 245-262.

Kumar S and Singh S (2006) Indian Nationalized Banks: An Empirical Study on Factors Influencing Competitiveness. Indian Journal of Industrial Relations 73-90.
Mohan TR and Ray SC (2004) Comparing performance of public and private sector banks: a revenue maximisation efficiency approach. Economic and Political Weekly 1271-1276.

Mohan TT (2002) Deregulation and Performance of Public Sector Banks. Economic and Political weekly 37(5): 393-397. Retrieved 22-08-2014 05:24 UTC, from http://www.jstor.org/stable/4411684

Reddy SK (2012) Relative Performance of commercial banks in India using CAMEL approach. International Journal of Multidisciplinary Research 2(3): 38-58.

Roman A and Şargu AC (2013) Analysing the financial soundness of the commercial banks in Romania: an approach based on the camels framework. Procedia economics and finance 6: 703-712.

Sensarma, R. (2005). Cost and profit efficiency of Indian banks during 1986-2003: a stochastic frontier analysis. Economic and Political Weekly 40(12): 1198-1209.

Singh AB and Tandon P (2012). A study of financial performance: A comparative analysis of SBI and ICICI Bank. International Journal of Marketing, Financial Services \& Management Research 1(11). 